\title{
Legist Ratio on the Distribution of the Inheritance between Men and Women in order to Protect Women's Rights: Islamic Law Experience
}

\author{
Rizkisyabana Yulistyaputri and Sharfina Sabila \\ The Constitutional Court of the Republic of Indonesia, Central Jakarta, Indonesia
}

\begin{abstract}
.
A legal event called death will have various legal consequences; one of them is the distribution of property left by the deceased, namely inheritance. The proportion of distribution of inheritance assets often creates disputes between the parties. In Islamic law, the distribution of inheritance is regulated in detail in the Qur'an as the main source of law. Generally, it gives a greater share of the inheritance to male heirs rather than to female heirs, with a ratio of 2: 1 . This differentiation based on gender seems to be unfair for women. In fact, this arrangement actually gives protection for women in a society. Based on Qur'an, Hadits, and postive law in Indonesia, it can be seen how Islam protects women with the provision of the distribution of inheritance. This article will discuss from the perspective of Islamic Law on how to distribute the proportion of inheritance between men and women in order to protect the basic rights of a woman.
\end{abstract}

Keywords: Islamic Law; Inheritance; Women; Rights; Protection

\section{Introduction}

Inheritance law is part of family law, where the existence of family law itself cannot be separated from the enactment of civil law in effect in Indonesia. The law of inheritance comes from a legal event known as death. After the death, there will be problems regarding the rights and obligations of the deceased person. Surini Ahlan Sjarif said "Inheritance Law is the law of property in the family law environment, because of the death of a person, there will be a transfer of assets left by the dead and the consequences of this transfer for people who get it both in the relationship between them and between them with third parties" (Surini Ahlan Sjarif, 1983). When a person dies, at that time all the rights and obligations of the deceased person pass on to his heirs.

Due to the diversity of the population in Indonesia, there are three types of inheritance law in society, namely Inheritance Law based on the Civil Code (BW), Islamic Inheritance Law, and Customary Inheritance Law. The enactment of the three inheritance laws is based on the existing population groups in Indonesia, namely as follows:

1. Customary Inheritance Law applies to Indigenous Indonesians;

2. Islamic inheritance law applies to Indonesians who are Muslim; 


\section{2nd Global Conference on Women's Studies}

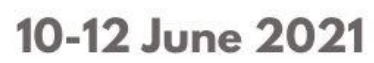

Berlin - Germany

3. Civil Inheritance Law (BW) applies to Chinese and European (descendants).

For an inheritance process to occur, at least three elements are required, namely deceased, heir, and inheritance. A deceased is a person who dies and leaves his property to someone else (Mulyadi, 2008). The heir is someone who replaces the position of the testate to the inheritance, either in whole or in part. Regarding this heir, can happen to be an heir based on the law or law applicable to the heir, as well as heirs who get their rights from the testament. Inheritance itself is several assets left by people who have died.

The position of women as heirs in Islamic Inheritance Law is clearly stated in the Qur'an in Surah An-Nisa verse 11, which means "Allah requires (obliges) you about (distribution of inheritance for) your children, (namely) the part of a child. the male is equal to the share of two daughters. And if the children are all more than two women, then their share is two-thirds of the property left behind. If she (daughter) is alone, then she gets half (the property left behind). And for both mother and father, each share one-sixth of the property left, if he (who died) had children. If he (who dies) does not have a child and he is inherited by his (only) mother-father, then the mother gets one-third. If he (who died) had several siblings, then the mother got one-sixth. (The distribution mentioned above) after (fulfilled) the will made or (and after being paid) the debt. (Regarding) your parents and your children, you do not know which of them is more beneficial to you. This is the decree of Allah. Truly, Allah is AllKnowing, All-Wise"

The application of Islamic Law in Indonesia itself, including matters of inheritance, is fully regulated in the Islamic Law Compilation (ILC). Article 176 ILC states that "A girl if only one person gets half of the share, if two or more people together with get two-thirds of the share, and if a girl is together with a boy, then the boy's share is two to one with girls"

From this description, it is clear that the share of woman in Islamic inheritance law is less than that of man. This article will answer how the distribution of inheritance is based on Islamic law. Furthermore, it will be explained how the distribution of inheritance based on Islamic law is a form of protection for women and not gender inequality.

\section{The Distribution of Inheritance in Islamic Law}

Fara'idl, which means division, is the title of inheritance law in Islam. Islamic inheritance law adheres to the rules written in the Qur'an as the highest source of law. As a complement and to elaborate the written rules in the Qur'an, the sunnah of the Prophet Muhammad, along with ijtihad, which is the effort of leading Islamic jurists.

Some of the verses in the Qur'an which regulate the provisions in Islamic inheritance law are as follows:

a. Surah An-Nisa verse 7

For men, there is a right to share the inheritance of both parents and relatives, and for women, there is a right to share (also) from the inheritance of both parents and relatives, either a little or a lot according to a predetermined share.

b. Surah An-Nisa verse 8

And if during the distribution there are some relatives, orphans and poor people, then give them from that treasure (in moderation) and say good words to them.

c. Surah An-Nisa verse 11 


\title{
2nd Global Conference on Women's Studies
}

\author{
10-12 June 2021
}

Berlin - Germany

Allah requires (obliges) you about (distribution of inheritance for) your children, (namely) the part of a child. the male is equal to the share of two daughters. And if the children are all more than two women, then their share is two-thirds of the property left behind. If she (daughter) is alone, then she gets half (the property left behind). And for both mother and father, each share one-sixth of the property left, if he (who died) had children. If he (who dies) does not have a child and he is inherited by his (only) mother-father, then the mother gets one-third. If he (who died) had several siblings, then the mother got one-sixth. (The distribution mentioned above) after (fulfilled) the will made or (and after being paid) the debt. (Regarding) your parents and your children, you do not know which of them is more beneficial to you. This is the decree of Allah. Truly, Allah is All-Knowing, AllWise

d. Surah An-Nisa verse 12

And you shall have half of what your wives leave if they have no child, but if they have a child, then you shall have a fourth of what they leave after (payment of) any bequest they may have bequeathed or a debt; and they shall have the fourth of what you leave if you have no child, but if you have a child then they shall have the eighth of what you leave after (payment of) a bequest you may have bequeathed or a debt; and if a man or a woman leaves property to be inherited by neither parents nor offspring, and he (or she) has a brother or a sister, then each of them two shall have the sixth, but if they are more than that, they shall be sharers in the third after (payment of) any bequest that may have been bequeathed or a debt that does not harm (others); this is an ordinance from Allah: and Allah is Knowing, Forbearing.

e. Surah An-Nisa verse 33

And to every one We have appointed heirs of what the parents and near relatives leave; and as for those to whom your oaths have been tied, give them their share as well; surely Allah is a Witness over all things.

f. Surah An-Nisa verse 176

They ask you for a legal ruling. Say: "Allah gives you a decision concerning the kelâle (person who has neither parents nor children). If it is a man that dies leaving a sister, but no child, she shall have half of what he leaves. And he shall be her heir if she has no son. If there are two sisters, they shall have two-thirds of what he leaves; and if there are many brothers and sisters, the male will have twice the share of the female. Allah makes it clear to you lest you get lost. Allah is AllKnowing of all things"

The three main principles of inheritance in Islamic Law are:

1. Family members who are entitled to inherit first are male relatives of the father's closest party, known as ashabah;

2. Women and family members from the maternal line do not have inheritance rights

3. His offspring, namely children, grandchildren, great great-grandchildren, are more entitled to inherit from the heir ancestors, namely their father, brother, or greatgrandfather

When a person dies and leaves some properties, these assets can be inherited from his heirs. The basis for a person's right to inherit property is as follows: (Eman Suparman, 2018) 


\section{2nd Global Conference on Women's Studies}

10-12 June 2021

Berlin - Germany

1. Having a blood relationship with the heir;

2. Having an affair or relationship caused by marriage;

3. There is a brotherly relationship, because of the religion determined by the Qur'an, the share is not more than one-third of the inheritor's assets;

4. There is a relative relationship because one another hijrah at the beginning of the development of Islam, even though there is no blood relationship.

In Islamic inheritance law, heirs are classified into three groups, namely:

a. Dzul faraa'idh

For this group of heirs, their share of the inheritance has been clearly defined in the Qur'an, the share is permanent and cannot be changed. The legal basis for the heirs of dzul faraa'idh is Quran Surah An-Nisa verses 11 (eleven), 12 (twelve), and 176 (one hundred and seventy-six).

The heirs included in this group are daughters, daughters from sons, fathers, mothers, grandparents from the paternal line, grandmothers from both the paternal and maternal lines, sisters who are the same father and one thousand from the paternal line, sisters half-brothers from the paternal line, half-brothers from the maternal line, half-sisters from the maternal line, widowers, and widows.

In the Islamic Law Compilation (ILC), this class of heirs is regulated in Book II, Chapter II, in article 174, which reads:

1. The groups of heirs consist of a. According to blood relations: - male groups consist of father, son, brother, uncle, and grandfather. - The female group consists of: mothers, daughters, sisters from grandmothers. b. According to the marital relationship consisting of widowers or widows.

2. If all heirs are present, only children, fathers, mothers, widows, or widowers are entitled to inherit.

The part of the heirs is explained in the Qur'an, which is as follows: (Eman Suparman, 2018)

1. Receiving $1 / 2$ (half) of the inheritance:

a. A girl if there are no boys (Surah An-Nisa verse 11);

b. A daughter of a son, when there are no grandchildren, a daughter;

c. A biological sister, if there is no brother (Surah An-Nisa verse 176);

d. A sister from the same age, when there are no brothers (Surah An-Nisa verse 176);

e. Husband if the wife who dies does not leave her children or grandchildren (Surah An-Nisa verse 12)

2. Obtain $1 / 4$ (one-quarter) of the inheritance:

a. Husband, when the wife who dies has children or grandchildren (Surah An-Nisa verse 12);

b. Wife, if the husband who dies does not leave his children or grandchildren (Surah An-Nisa verse 12)

3. The wife, whether one or more, gets $1 / 8$ (one-eighth) of the inheritance if the husband who dies leaves a child, either a boy or a girl (Surah An-Nisa verse 12). Likewise, when the husband dies and leaves the children of boys, both boys and girls.

4. Receive 1/3 (one-third) of the inheritance: 


\section{2nd Global Conference on Women's Studies}

10-12 June 2021

a. Mother, when the heir does not leave a child or grandchild, or two or more siblings (Surah An-Nisa verse 11);

b. Two or more voices of a thousand, both brothers and sisters, with the same distribution.

5. Receive 2/3 (two-third) of the inheritance:

a. Two or more girls when there are no boys (Surah An-Nisa verse 11);

b. Two granddaughters or more from son, daughters;

c. Two or more sisters when there is no brother (Surah An-Nisa verse 176);

d. Two or more siblings, when there is no brother (Surah An-Nisa verse 176)

6. Obtain 1/6 (one-sixth) of the inheritance:

a. Mother, if the heir leaves children, grandchildren, two or more siblings (Surah An-Nisa verse 11);

b. Father, if the heir has children or grandchildren (Surat An-Nisa verse $11)$;

c. Grandmother, mother from father;

d. A granddaughter, from son together with daughter;

e. Grandfather, father of father, along with children or grandchildren, when the father is not around;

f. A sibling, male or female (Surat An-Nisa verse 12)

g. Sister, one or more siblings at the same time.

a. Ashabah

The word ashabah in Arabic is used specifically for male relatives, so it is drawn from the paternal line. This group of heirs will get a share of the inheritance when the share of the heirs of dzul faraa'idh has been divided completely and has the remainder. So, when the testate does not have the heir class of Dzul faraa'idh, then the inheritance left behind will be inherited to the class of heirs ashabah.

The class of ashabah heirs is divided into 3 (three) groups, namely Ashabah Binafsihi, Ashabah bilghairi, and ashabah ma'al ghairi. The Ashabah Binafsihi group has the right to all of the remaining assets of the testate, and consists of only men, namely boys, grandchildren of boys and continues down as long as there is a relationship that is still male, father, paternal grandfather and continuing upwards provided that the relationship has not been broken from the father's side, sibling brothers, siblings, siblings' children, brothers from the same family, uncles who share with the father's father, uncle's son who is the same parent with father, and uncle's son who is the same as father.

Ashabah bilghairi is a sister who needs someone else to be able to become ashabah, which are daughter who inherits with a son, a granddaughter who inherits along with her grandchildren, and a sister who inherits along with her brother.

Ashabah ma'al ghairi are female relatives who inherit together with the descendants of the heir, which are the siblings of the siblings, and also the sisters of the father who inherit together with their daughters and granddaughters.

b. Dzawil-arham

Dzawil-arham heirs are relatives who are related by blood to the heir through the female lineage. Dzawil-arham heirs can inherit when there are no heirs for $d z u l$ 


\section{2nd Global Conference on Women's Studies}

10-12 June 2021

Berlin - Germany

faraa'idh and ashabah. Grandchildren through daughters and other blood relatives whose liaison is a woman.

In Islamic law of inheritance, there is also a priority group of heirs, who will be prioritized to inherit compared to other heirs. This priority group consists of:

1. The first virtue

The priority group consists of children of the deceased, both boys, and girls, or the successor heirs to the position of the deceased child, and fathers, mothers, and widows or widowers when there are no children.

2. Second virtue

The second class of virtue consists of the siblings of the deceased, whether brother or sister, or the successor to the position of a deceased relative, and father, mother and widow or widower when there are no other relatives.

3. The third virtue

Mother and father if there is a family, mother, and father if one if there are no children and no siblings, as well as a widow or widower, fall into the third priority group

4. The fourth virtue

A widow or two, as well as a substitute heir for the mother and an heir for a father's position, are included in the fourth group of virtues in Islamic law of inheritance.

\section{Protection of Women's Rights in Islamic Inheritance Law}

In Islamic Law, the distribution of inheritance between male and female is $2: 1$. It is stipulated in Qur'an Surah An-Nisa:11 which says Allah instructs you concerning your children [i.e., their portions of inheritance]: for the male, what is equal to the share of two females. In this verse, an heir can get twice more than an heiress. Thus, this kind of arrangement which based on gender seems to be unjust for woman becase an heiress get less than an heir. This part will focus on reasoning how this kind of distribution is not a form of discrimination against woman. In contrary, this arrangement can be seen as a form of protection for women in society. Based on Qur'an, Hadits, and postive law in Indonesia, it can be seen how Islam protects women with the provision of the distribution of inheritance.

From Islam's point of view, justice is the starting point, process and goal of all human action. In relation to the material, which is regulated in inheritance law, justice can be interpreted as a balance between rights and obligations, a balance between what is obtained with its needs and uses (Mohammad Daud Ali, 2006). Moreover, justice is not only measured by the amount obtained when receiving inheritance rights but also related to uses and needs. Because in general, men need more material than women. This is because men in Islamic teachings assume a double obligation, namely for themselves and their families, including women; as explained by Allah (SWT) in Qur'an Surah An-Nisa: 34 (Maryati Bachtiar, 2012).

Allah instructs you concerning your children [i.e., their portions of inheritance]: for the male, what is equal to the share of two females (Qur'an, 4:11). This verse means that Allah (SWT) has determined who will be the heirs and the parts obtained by the heirs as well as the inheritance of sons and daughters have the same position and rights in terms of receiving an inheritance. It is crystal clear that the portion of inheritance between man and woman in Islam. Male will receive two shares of the female, which is a larger share of inheritance rather 


\title{
2nd Global Conference on Women's Studies
}

\author{
10-12 June 2021
}

Berlin - Germany

than women. As the main source of Islamic Law, this provision can not be waived by moslems. At first glance, this provision reflects injustice for women. Especially, in the era of globalization and modernization that echo the need for gender equality in society. This provision seems like there is a discrimination on women regarding gender. Nonetheless, the meaning is contrary to what it seems in a glance. It aims to protect the women in a society. This argument based on the obligation of husband in a family, nafqah concept, and positive law in Indonesia.

In Islamic Inheritance Law, it is known that men receive twice the share received by women, in essence half or even more than half of that amount is not for the benefit of himself (man) himself. It shares for his wife and family. If he does not have an obligation to make a living for them, then one shares of the inheritance is enough for himself, as it already enough for single man. The difference in the portion is not due to gender issues, but on the difference in duties and responsibilities assigned to men is greater than those imposed on women in the context of Islamic society, according to the conventional standard theory which states that: "The bigger and heavier the burden a man bears, the greater the rights he will get", because the costs he has to pay to carry out the said responsibility are greater (Muhammad Ali Murtadlo, 2018).

In Qur'an, Allah (SWT) gives a clear position of men and women in a family. "Men are the caretakers of women, as men have been provisioned by Allah over women and tasked with supporting them financially" (Qur'an, 4:34). Men act as a guardian for his wives, so that he should bear the responsibilities to give nafqah for his family. Furthermore, Allah (SWT) does not burden a soul beyond that he/she can bear. "Mothers may nurse [i.e., breastfeed] their children two complete years for whoever wishes to complete the nursing [period]. Upon the father is their [i.e., the mothers'] provision and their clothing according to what is acceptable. No person is charged with more than his capacity. No mother should be harmed through her child, and no father through his child. And upon the [father's] heir is [a duty] like that [of the father]. And if they both desire weaning through mutual consent from both of them and consultation, there is no blame upon either of them. And if you wish to have your children nursed by a substitute, there is no blame upon you as long as you give payment according to what is acceptable. And fear Allah and know that Allah is Seeing of what you $d o "$ (Qur'an, 2:233). It can be seen that the obligation to give nafaqah according to what is accetable based on mutual consent between husband and wive in a family.

"Let the man of wealth provide according to his means. As for the one with limited resources, let him provide according to whatever Allah has given him. Allah does not require of any soul beyond what He has given it. After hardship, Allah will bring about ease" (Qur'an, 65:7). This verse explain man's obligation to fullfill his family's need based on his ability. Onthe other hand, woman as a wives is not obliged to spend any of her wealth (if any) for her family. Thus, she has the right to receive the "living" form her husband as it is his obligation to fullfill it.

The word nafaqah is linguistically derived from the Arabic anfaqa, yunfiqu, infaqan, nafaqatan. It means issuing, infaq means al-mashruf wa al-infaq, shopping costs, spending money, and living expenses. Nafaqah is then used to refer to something that is given to a person who is dependent on it. (Maharati Marfuah, 2020). Thus, it can means all forms of expenditure for himself and his family from food, clothing and a place to live. Providing a 


\section{2nd Global Conference on Women's Studies}

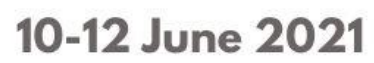

Berlin - Germany

nafaqah is an obligation and responsibility that should not be violated and must be fulfilled by the husband for his wife and parents towards their children.

Husband and wife, or father, mother, and children, who are under one household are the smallest unit of the family. This unit requires a leader, and in the view of the Qur'an who is reasonable to lead is the father. The reason is firstly, because Allah has exaggerated some of them over some of the others, and secondly because they (husbands are obliged) to spend part of their assets (for their wives/his family) (M. Quraish Shihab, 1996). The reasons for obligation to provide a nafaqah can be classified into 3 (three), such as: 1) relative/descent relationship; 2) ownership; and 3) marriage (Abdurrahman al-Jaziri, 1969).

In this context, nafaqah is not only a gift that is provided by a husband to his wife, but also an obligation of the father to his child and the responsibility of an owner to something. This responsibilities have been ruled in Qur'an and Hadith, which rules in the Qur'an Surah AthThalaq: 6, Al-Baqarah: 233, and more. The need means an obligation that must be done by the form of expenditures related to the basic needs of both the husband against the wife and father of the child or his family. Due to its importance of it in the study of Islamic law, even a wife who has been thalaqed by her husband still has the right to earn a living for themselves and their children (Syamsul Bahari, 2015).

Moreover, it is needed to look at Ikhwanus Safa's thought as cited by Asghar Ali Engineer in his book "The Rights of Women in Islam". Brother, many of the intellectuals who engage themselves in the study of philosophy and metaphysics when they reflect with their own thoughts, directions and understanding, their judicious acumen ijtihad and comparative reasoning (ciyas) lead them to feel that most of the divine prescriptions appear to be against justice, truth and rectitude. All this is because of their deficiency in understanding, paucity of discretion and lack of knowledge about the essence of the secrets of the divine law. For example, when they reflect upon the rule of inheritance that a male will have twice the share of a female, they feel that the correct position should have been the female getting twice the portion of a male. For women are feeble and have no avenues for earning money. They (the intellectuals) do not know and understand that the rule laid down in the divine law actually leads to what they hint at and desire for. In this manner, the Divine Law would produce the result they have desired and hinted at. This is the manner you should look at the Divine Law so that the exact rectitude and substance of truth could become apparent. One should be aware that the insight of the Law-giver in the requirements of his laws in not a partial and fragmentary insight, for the benefit of some and to the exclusion of others, or for the ready present (transitoriness) to the exclusion of the future (eternity, but it is an absolute insight aiming at the good and rectitude of all, for the present as well as the future (Ikhwanus Safa).

In another case, if a daughter cannot marry for some reason and she is not well provided for, the parents can make a special request in her favour, compensating her for her deprivation. Thus, one can say with certainty that the Qur'an takes care of women, who are considered weaker in society, in a fairly reasonable way. If the Qur'anic provisions in respect of inheritance are implemented faithfully, the women would benefit greatly. The only condition for successful implementation of the Qur'anic provision is that the Shari'ah as formulated by the early jurists should not be treated as final and, wherever necessary, should be reinterpreted or even reformulated in the true qur'anic spirit in view of the changed conditions and new consciousness of women (Asghar Ali Engineer, 2008). 


\section{2nd Global Conference on Women's Studies}

10-12 June 2021

Berlin - Germany

In Inheritance Islamic Law, there are some principles such as a)ijbari, b)bilateral, c)individual, d)proportional justice, and e)result of death. one of them is proportional justice. This principle means that there should always be balance between rights and obligation, between rights acquired by someone, with the obligations that must be fulfilled. for example, men and women have rights that are proportional to the obligations they assume (later) in family and community life. In the Islamic inheritance system, the inheritance received by the heirs from the deceased is essentially a continuation of the responsibility of the heir to his family. therefore, the difference in the share received by each heir is proportional to the difference in the responsibilities of each heir in proportion to the difference in the responsibilities of each to the family (Muhammad Daud Ali, 2006).

The position of heiress is equal to heir, in line with "proportional justice" principle. This principle means the rights between heir is the same and equal. The phrase "justice principle" is the heir have rights and duties, and between them should be proportional. For example, the share between heir and heiress is $2: 1$. It is due to the heir's obligation to make a living for his child and wives. While the heiress do not have any obligation to give her wealth for her family (Muhammad Daud Ali, 2006).

A man is responsible for family life, to provide for his wife and children (Qur'an, 2: 223) according to his ability (Qur'an, 65: 7). This responsibility is a religious obligation that he must carry out, regardless of whether his wife is capable or not, his child needs help or not. To other relatives, a man's responsibility is only additional, the legal sunnah, if he wants and is able to carry it out. Based on the balance between the rights obtained and the obligations that must be fulfilled, actually what a man and a woman get from an inheritance, the benefits will be the same they will feel. (Muhammad Daud Ali, 2006)

Furthermore, in Indonesia there are 3 (three) inheritance legal systems available for Indonesian people as mentioned before. In society, many people implement the inheritance system based on Customary Law and Islamic Law. There are 2 (two) kind of family system which affect it, namely patrilineal (paternal line which which children inherit only from their father) and matrilineal (maternal line which children inherit only from their mother). In this context, we should look further on the thought of Hazairin between Customary Law and Islamic Law.

According to Hazairin, if we want to study the kinship or inheritance system, we must study the marriage system in that society (Hazairin,1982). The inheritance system cannot be separated from the form of kinship which originates in the system (principle) of descent which in turn is also influenced by the form of marriage. The laws of marriage and inheritance comes from lineage (Hazairin, 1976). In his point of view, the kinship system that Qur'an wants is bilateral, while the entire family system apart from the it is heading towards bilateral. The bilateral system in Islamic Inheritance Law, is a principle trying to equalize men and women in terms of inheritance. According to Hazairin, there is no problem in the distribution of inheritance between men and women, because of they have equal rights, rights and positions which equalized does not mean having the same number of amount but having the same right to receive inheritance as well as a kin's inheritance system drawn from male and female lineages (father and mother lines), while the number of it determined by the rules of Allah. Inheritance rights of women different from men cannot be called unfair because a man has a greater responsibility (Beni Ahmad Saebani, 2012). Surah An-Nisa:11 describes all 


\section{2nd Global Conference on Women's Studies}

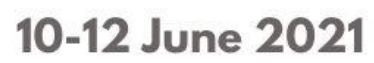

Berlin - Germany

children, both male and female, become heirs for their parents (mother and father). Thus, it is neither patrilineal nor matrilineal; which can be interpreted based on Hazairin is bilateral.

In a more general context of Islamic Inheritance Law (faraidh), Imam Qurtubi says on how important faraidh in our daily life, "If we already know the nature of this knowledge, then how high and great is the knowledge of the companions about faraidh. It is amazing how their view on this inheritance. However, it is very unfortunate for most humans (especially nowadays) ignore and abuse it."(Abi Abdillah). Hence, due to its importance the provisions of Allah (SWT) in Qur'an should be interpret carefully and cannot be neglect by moslems.

\section{Conclusion}

Qur'an is the main source of law for moslems. In Islamic Inheritance Law, there is a provision on distribution of inheritance between men and woman $(2: 1)$ in which men receive more shares rather than woman. The finding shows that it is due to men's greater responsibilities (rather than woman) in a family, he bears the obligation of nafaqah for his family. Thus, his shares are not only for him but for the others. Furthermore, in Indonesia it can be known from Hazairin that men and women receive inheritance from their father and mother (bilateral principle). Justice does not mean men and women receive the same amount of inheritance's shares. Islam shows "proportional justice" principle in this arrangement to gives protection for women in a marriage framework because men is the head of family.

\section{References}

\section{(Books)}

Abdillah, Abi. Tafsir al-Qurtubi. Beirut-Lebanon: Dar al-Fikr.

Al- Jaziri, Abdurrahman. (1969). Kitab Fiqh ala Madzhab al-Arbaah, Juz IV. Beirut.

Ali, Mohammad Daud. (2006). Hukum Islam: Pengantar Ilmu Hukum dan Tata Hukum Islam di Indonesia). Jakarta: PT. Raja Grafindo Persada.

Engineer, Asghar Ali. (2008). The Rights of Women in Islam. New Delhi: Sterling Publishers Pvt. Ltd.

Marfuah, Maharati. (2020). Hukum Fiqih Seputar Nafkah. Lentera Islam.

Hazairin. (1976). Hendak Kemana Hukum Islam. Jakarta: Tintamas.

Hazairin. (1982). Hukum Kewarisan Bilateral Menurut Alquran dan Hadith. Jakarta: Tintamas, p. 11.

Mulyadi. Hukum Waris Tanpa Wasiat. Semarang: Badan Penerbit Universitas Diponegoro.

Nasution, Khoiruddin. (2004). Islam Tentang Relasi Suami dan Istri (Hukum Perkawinan I) Dilengkapi Perbandingan Undang-undang Negara Muslim. Yogyakarta: Tazzafa Academia.

Saebani, Beni Ahsmad. (2012). Fiqih Mawaris. Bandung: Pustaka setia.

Shihab, M. Quraish. (1996). Wawasan Al-Qur'an: Tafsir Maudhu'i atas Pelbagai Persoalan Umat. Bandung: Mizan. 


\section{2nd Global Conference on Women's Studies}

10-12 June 2021

Berlin - Germany

Sjarif, Suruni Ahlan. (1983). Intisari Hukum Waris Menurut BW. Jakarta: Ghalia Indonesia.

Suparman, Eman. (2018). Hukum Waris Indonesia (Dalam Perspektif Islam, Adat, dan BW). Bandung: PT Refika Aditama.

\section{(Journal)}

Bachtiar, Maryati. (2012). "Hukum Waris Islam Dipandang Dari Perspektif Hukum Berkeadilan Gender,"Jurnal Hukum, vol. 3, No.1.

Bahari, Syamsul. (2015). "Conjugal Need Concept in Islamic Law". Kanun Jurnal Ilmu Hukum, No.66, p. 381-399.

Murtadlo, Muhammad Ali. (2018). "Keadilan Gender Dalam Hukum Pembagian Waris Islam Perspektif The Theory Of Limit Muhammad Syahur". Gender Equality: International Journal of Child and Gender Studies, vol.4, No.1. p.183. 